\title{
The role of IGF-I in the development of cardiovascular disease in type 2 diabetes mellitus: is prevention possible?
}

\author{
J A M J L Janssen and S W J Lamberts \\ Department of Internal Medicine, Erasmus University Medical Centre, Rotterdam, The Netherlands
}

(Correspondence should be addressed to Joop Janssen, Department of Internal Medicine, Room D438, Erasmus University Medical Centre Rotterdam, Dr Molewaterplein 40, 3015 GD Rotterdam, The Netherlands; Email: janssen@inw3.azr.nl)

\begin{abstract}
The incidence of peripheral, cerebro- and cardiovascular disease (CVD) in patients with type 2 diabetes mellitus is approximately twice as high as in the non-diabetic population. Conventional cardiovascular risk factors such as plasma lipids, lipoproteins and hypertension only partially explain this excessive risk of developing atherosclerosis and CVD. Meta-analysis of studies performed in nondiabetic populations indicates that the risk of CVD increases continuously with glucose levels above $4.2 \mathrm{mmol} / \mathrm{l}$. The glucose hypothesis suggests that treatment which normalizes glucose levels prevents or delays the long-term complications of diabetes mellitus. However, the outcome of the UK Prospective Diabetes Study demonstrates that glucose control does not completely prevent CVD. In healthy subjects, serum IGF-I levels peak in early adulthood, after which they gradually decrease with increasing age. Several observations suggest that there is a premature and progressive agerelated decline in serum IGF-I bioactivity in type 2 diabetics, which eventually results in a (relative) IGF-I deficiency. In type 2 diabetics, close relationships have been demonstrated between glycaemic control and serum IGF-I levels, with worse control being associated with lower IGF-I levels. Several studies (in non-diabetics) suggest that lowered circulating IGF-I levels account for a poor outcome of CVD. We previously observed in a population-based study that a genetically determined lowered IGF-I expression increases the risk of myocardial infarction with type 2 diabetes.

This genetic approach overcomes the problem that cross-sectional studies cannot distinguish whether changes in IGF-I levels are a cause or a consequence of a disease. IGF-I is an important metabolic regulatory hormone. In addition, IGF-I suppresses myocardial apoptosis and improves myocardial function in various models of experimental cardiomyopathy. Compared with other growth factors, the 'survival' effect of IGF-I on myocardium seems rather unique.

Therefore, we hypothesize that the premature and progressive decline in serum IGF-I bioactivity in ageing patients with type 2 diabetics is an important pathophysiological abnormality. It contributes not only to elevated glucose and lipid levels, but also to the progression and the poor outcome of CVD. If this hypothesis is proven to be right, treatment with IGF-I as an adjunct to insulin offers great potential and might not only improve metabolic control but also reduce the incidence and prevalence of CVD in type 2 diabetes patients. However, there is as yet no experimental evidence that long-term (replacement) treatment with IGF-I prevents, delays or reduces CVD in type 2 diabetes patients. Clinical trials are necessary to prove that long-term IGF-I treatment, preferably in the form of a bettertolerated IGF-I/IGF-binding protein-3 complex, improves the overall cardiovascular risk in type 2 diabetes.
\end{abstract}

European Journal of Endocrinology 146 467-477

\section{Introduction}

The incidence of cardiovascular disease (CVD), particularly coronary heart disease (CHD), cerebrovascular, and peripheral vascular disease is approximately twice as high in patients with type 2 diabetes as in agematched controls without diabetes $(1-4)$. The risk of these complications increases with the duration of diabetes and with age (5-7). In subjects with type 2 diabetes, CVD is associated with a higher mortality rate than in non-diabetic subjects $(8,9)$. Conventional cardiovascular risk factors such as plasma lipids, lipoproteins and hypertension only partially explain this excessive risk of developing atherosclerosis and CVD in individuals with type 2 diabetes $(6,10)$. In addition, despite a marked decline in the rate of CVD over the past 35 years in the overall population, this beneficial trend has not been observed for subjects with type 2 diabetes (11).

Another important manifestation of CVD in diabetic patients is heart failure (HF). The special role of diabetes in the development of congestive HF was 
firmly established in the Framingham Study (12). In this study the risk of HF was increased 2.4-fold in diabetic men and 5-fold in diabetic women. Diabetes predicted HF independently of coexisting hypertension or CHD. HF is sometimes due to a diabetic cardiomyopathy, which is now recognized as a distinct entity (13). Diabetic cardiomypathy appears to be independent of macrovascular/microvascular disease and contributes significantly to CVD morbidity and mortality, especially in those diabetics with coexistent hypertension (14). Abundant literature evidence supports the concept of myocardial dysfunction separate from epicardial coronary disease in diabetic individuals $(15,16)$.

\section{Glucose control, insulin treatment and CVD in the UK Prospective Diabetes Study (UKPDS)}

The glucose hypothesis suggests that treatment that normalizes glucose levels prevents or delays the longterm complications of diabetes mellitus. Based on the UKPDS it has been suggested that the benefits of strict glycaemic control in type 2 diabetes are less than those of tight blood pressure control (17). Although in the primary analysis of the UKPDS no significant reduction in the risk of CVD was observed after strict glycaemic control, mean glycosylated haemoglobin (HbA1c) levels achieved in the UKPDS did not reach the non-diabetic (normal) range. In addition, epidemiological subanalysis of the UKPDS data suggested that a reduction of $\mathrm{HbA} 1 \mathrm{c}$ levels by $1 \%$ was associated with a $14 \%$ reduction in myocardial infarctions and a $12 \%$ reduction in strokes (18). These epidemiological data show that glucose-directed therapy which is sufficient to lower glucose levels to normal produces a 'normal' population risk for macrovascular problems. Nevertheless, the overall outcome of the UKPDS makes clear that CVD cannot be completely prevented by the common methods of blood glucose control which are clinically available today (19).

\section{Impaired glucose tolerance (IGT), hyperinsulinaemia, insulin resistance and CVD}

It has long been known that even IGT is associated with an increased risk for CVD, while progression from IGT to type 2 diabetes is not necessary in order to cause CVD (20). The Whitehall study, the Honolulu Heart Study and the Rancho Bernardo Study have prospectively followed large cohorts of non-diabetic subjects for cardiovascular outcomes $(21-23)$. In these three studies a continuous increase in the risk for CHD was observed with increasing serum glucose levels. In accord, a meta-analysis of various cohort studies in non-diabetic populations demonstrated that the increased risk of CVD increased continuously with glucose levels above $4.2 \mathrm{mmol} / \mathrm{l}$ (24). All these studies suggest that long-term hyperglycaemia is an important risk factor for CVD, without evidence of a threshold effect and independently of other common risk factors for CHD. Furthermore, subjects with insulin resistance who are not diabetic, e.g. patients with the metabolic syndrome X characterized by hypertriglyceridaemia, hypertension and abdominal obesity, are also at increased risk of CVD (25).

\section{Insulin-like growth factor-I (IGF-I), insulin and the IGF-binding proteins (IGFBPs)}

In man there are two important glucose-regulating hormonal systems, insulin and IGF-I (26). In the human body, IGF-I is after insulin the second most powerful naturally occurring peptide with glucoselowering effects (27). The effects of IGF-I and insulin are complementary. Insulin stimulates the constitutive secretion of IGF-I from the liver (28). IGF-I in turn, suppresses insulin secretion even in euglycaemic conditions (29). IGF-I increases insulin sensitivity and peripheral glucose uptake, decreases hepatic glucose production, and improves the lipid profile $(30,31)$. IGF-I is probably the most potent anti-catabolic and anabolic hormone in the body (32).

At least six IGFBPs and several proteases modulate the bioavailability of IGF-I to the tissues (33). In the blood, where IGF concentrations are 1000 times higher than those of insulin, IGFBP-3 (the major form of the IGFBPs in the circulation) binds in healthy subjects at least $80 \%$ of IGFs as $140 \mathrm{kDa}$ complexes, which do not cross the capillary endothelium and therefore prevent the insulin-like action of IGFs (34). Under normal circumstances less than 1\% of IGF-I circulates in the free form (35). Nevertheless, these circulating IGF reserves may be mobilized in response to metabolic and other needs via limited proteolysis of IGFBP-3 by serine proteases (36).

\section{Ageing, glucose metabolism and insulin resistance}

Ageing is characterized by progressive alterations in glucose metabolism, including resistance to insulinmediated glucose disposal, impaired glucose-induced insulin release and altered hepatic glucose output (37). The progression from normal glucose tolerance via IGT to diabetes is a consequence of a further decline in insulin secretion by the $\beta$-cell and/or an increase in insulin resistance with ageing (38). In addition, changes in body composition, as well as physical fitness, may contribute to a further reduction of insulin resistance with ageing. 


\section{Is there a progressive IGF-I deficiency in type 2 diabetes with ageing?}

In patients with type 2 diabetes, serum IGF-I levels are dependent on the degree of metabolic control, with near normal IGF-I levels in well-controlled diabetics, whereas they tend to decrease in poorly controlled diabetics (39-41). It has also been suggested that lowered serum IGF-I concentrations predict worsening of insulin-mediated glucose uptake in older people (42). In healthy subjects, serum total IGF-I levels peak in early adulthood and then start to decline to $50 \%$ of adolescent values in the fifth and sixth decades of life (43). In type 2 diabetes this progressive age-dependent decline of total IGF-I levels is even greater than that observed in healthy controls. Tan \& Baxter (44) reported that circulating total IGF-I levels are lowered in type 2 diabetic patients even after age was taken into consideration.

Although the mechanism for the progressive reduction of circulating IGF-I levels with ageing in patients with type 2 diabetes has remained obscure until now, it has been suggested that this decrease is at least in part a result of decreased IGF-I production through lowered growth hormone (GH) concentrations and/or an uncoupling of the $\mathrm{GH}$ induction of IGF-I generation by insulin resistance (45). Another explanation might be central inhibition of the GH/IGF-I axis. Increased demands for IGF-I with ageing, resulting in accelerated metabolic clearance rate of IGF-I by displacement of IGF-I from circulating IGFBP-3 and transport of IGF-I to peripheral tissues may also contribute to the progressive decrease of circulating IGF-I concentrations. It has been speculated that increased serum IGFBP-3 protease activity, as observed in insulin-resistant states and type 2 diabetes, is an endogenous compensatory mechanism to increase IGF-I bioavailability at the tissue level in order to restore insulin sensitivity, glycaemic control and other IGF-I-dependent effects (46-48).

It has also been reported that subjects with insulin resistance have initially decreased serum levels of IGFBP-1 in comparison with those without insulin resistance $(49,50)$. Although the biological significance of reduced circulating IGFBP-1 levels in insulinresistant/hyperinsulinaemic states is unknown, it has been suggested that low circulating IGFBP-1 concentrations might be another endogenous mechanism to increase IGF-I bioavailability at the tissue level in an attempt to stimulate glucose uptake in muscles and other insulin-resistant tissues (51). However, ageing and frank type 2 diabetes are both associated with a reduction of insulin secretory rate as a consequence of a progressive loss of $\beta$-cell function and this results in an increase in IGFBP-1 levels (50, 52-55). Increased IGFBP-1 levels are associated with a decreased IGF-I bioactivity in diabetic serum (56) and in vivo data in animals have shown that increased levels of IGFBP-1 can both inhibit IGF-I action and induce mild hyperglycaemia (57). All these findings together suggest that in type 2 diabetes during ageing there is a premature and progressive decline in serum IGF-I bioactivity, resulting in the development of a progressive (relative) IGF-I deficiency, especially in those with a poor metabolic control (see also Table 1).

\section{Age, genetic susceptibility, IGF-I and type 2 diabetes}

Age-related changes interact with the genetic background and may explain the increasing prevalence of

Table 1 Schematic time course of changes in circulating insulin, IGF-I/IGFBP levels and IGF-I bioactivity during the progression from impaired glucose tolerance (IGT) to overt type 2 diabetes. Blood glucose levels rise at first, resulting in IGT, and finally in overt type 2 diabetes. Initially, insulin secretion increases to overcome insulin resistance, but reaches a plateau and then falls. IGFBP-1 levels are thought to modulate the free fraction of IGF-I. IGFBP-1 levels are negatively regulated by insulin. It has been suggested that low IGFBP-1 concentrations might increase the free IGF-I concentration in an attempt to stimulate glucose uptake in muscles and other insulin-resistant tissues. The progression from IGT to frank type 2 diabetes is associated with a (relative) increase in IGFBP-1 levels and as a consequence IGF-I bioactivity decreases. Increased IGFBP-3 proteolysis has been reported to occur in insulin-resistant states and type 2 diabetes. It has been speculated that this increased protease activity in insulin-resistant states and diabetes is another compensatory mechanism to attenuate the decrease in free IGF-I concentrations in order to restore insulin sensitivity and glycaemic control. The physiological age-dependent decrease of IGF-I bioactivity is superimposed on the changes in circulating insulin and IGFI/IGFBP levels during the progression from IGT to overt type 2 diabetes (see also text).

\begin{tabular}{|c|c|c|c|}
\hline & \multicolumn{3}{|c|}{ Age $\longrightarrow$} \\
\hline & \multicolumn{3}{|c|}{$\overline{\text { Normo-glycaemia } \longrightarrow \text { IGT } \longrightarrow \text { Overt type } 2 \text { diabetes }}$} \\
\hline Insulin & $\mathrm{N}$ & $\uparrow$ & $\downarrow$ or $\downarrow \downarrow$ \\
\hline IGFBP-1 & $\mathrm{N}$ & $\downarrow$ & $\mathrm{N}$ or $\uparrow$ \\
\hline Total IGF-I & $\mathrm{N}$ & $\mathrm{N}, \downarrow$ & $\downarrow$ \\
\hline Free IGF-I & $\mathrm{N}$ & $\mathrm{N}, \downarrow$ & $\downarrow \downarrow$ \\
\hline Intact IGFBP-3* & $\mathrm{N}$ & $\mathrm{N}, \downarrow$ & $\downarrow \downarrow$ \\
\hline IGFBP3 protease activity & $\mathrm{N}$ & $\uparrow$ & $\uparrow \uparrow$ \\
\hline IGF-I bioactivity & $\mathrm{N}$ & $\mathrm{N}, \downarrow$ & $\downarrow \downarrow$ \\
\hline
\end{tabular}

$\mathrm{N}=$ normal; $\uparrow$ = increased; $\downarrow$ = decreased

* Measured by Western ligand blotting. 
type 2 diabetes and diabetic complications during the ageing process $(37,58)$.

Recently we observed in a population-based study of elderly subjects higher circulating total IGF-I levels in carriers of a genetic polymorphism in the promoter region of the IGF-I gene than in non-carriers (59). This study suggested that this IGF-I gene polymorphism is functionally related to circulating IGF-I levels (59). However, the main finding of this study was that both the risk of type 2 diabetes and myocardial infarction were significantly increased in non-carriers of this polymorphism when compared with carriers, suggesting that a genetically determined exposure to relatively low IGF-I levels plays a role in the pathogenesis of type 2 diabetes and myocardial infarction (59).

\section{IGF-I, diabetes and atherosclerosis}

GH and IGF-I deficiency in non-diabetic humans are associated with premature and increased atherosclerosis $(60-63)$. It was observed in hypophysectomized rats that after vascular endothelial injury the proliferation of vascular smooth muscle is markedly delayed, suggesting an impaired adaptive response in the process of healing of the injured arterial wall, when compared with healthy control animals (64).

Atherosclerosis is also a major cause of morbidity and mortality in patients with diabetes mellitus. Imbalance between cell death and survival may substantially affect the cellularity and integrity of the blood vessel and contributes to the pathogenesis of atherosclerosis (65). IGF-I is a potent survival factor preventing apoptosis of vascular smooth muscle cells (VSMCs) (66) as well as stimulating the proliferation (67) and migration

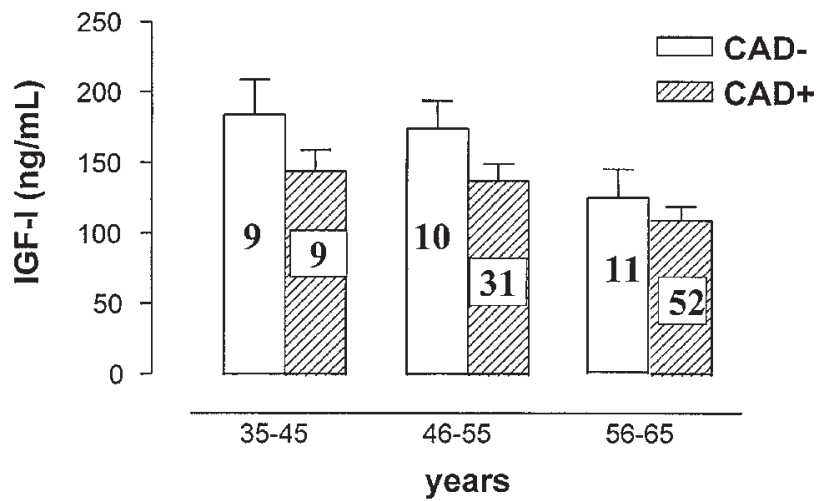

Figure 1 Circulating total IGF-I levels in patients with significant CAD $(C A D+)$ and in those without (CAD - ) stratified by decades of age. Each bar represents the mean \pm S.E.M. in each group. Values for the number of patients of each subgroup are shown in each box. Mean circulating total IGF-I levels were significantly lower $(P<0.01)$ in CAD+ patients $(126 \pm 7 \mathrm{ng} / \mathrm{ml} ; n=92)$ than in CAD - patients $(162 \pm 15 \mathrm{ng} / \mathrm{ml} ; n=30)$. When age was taken into account circulating total IGF-I levels were significantly lower in patients with CAD+ (two-way ANOVA, $P<0.05$ ). (Reprinted from (62) with permission from Excerpta Medica Inc.) of VSMCs (68). Thus, IGF-I may contribute in different ways to the balance between apoptosis and survival in atherosclerotic lesions (65).

IGF-I accumulation is found at the site of ischaemic injury and VSMC proliferation is an important part of the arterial response to injury (69). In an experimental animal model it has been observed that vascular smooth muscle proliferation after endothelial injury is impaired by the diabetic state (69). In this experimental model, IGF-I treatment enhances and normalizes vascular smooth muscle proliferation (69).

Circulating IGF-I levels, like insulin, stimulate nitric oxide (NO) in certain vascular beds (70-74). Reduced NO generation or accelerating NO inactivation may

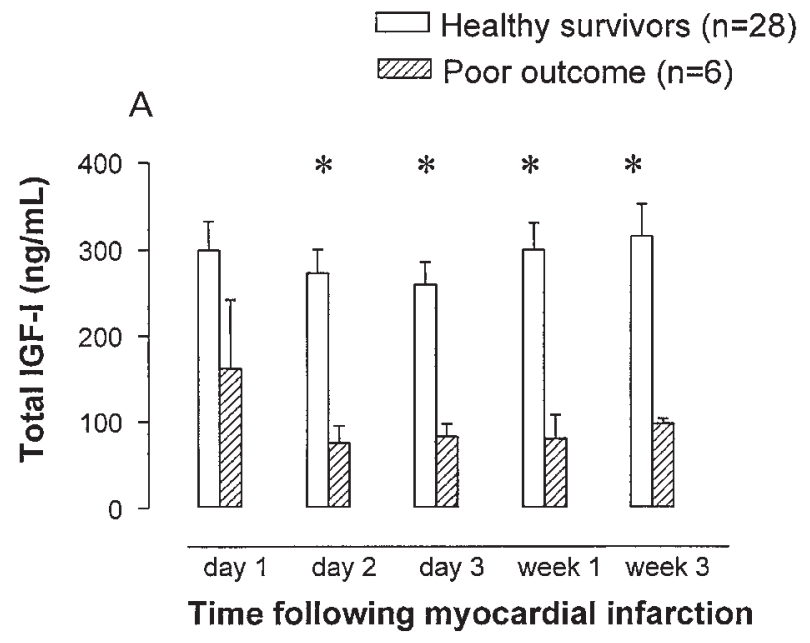

B

Healthy survivors $(n=28)$ एII] Poor outcome $(n=6)$

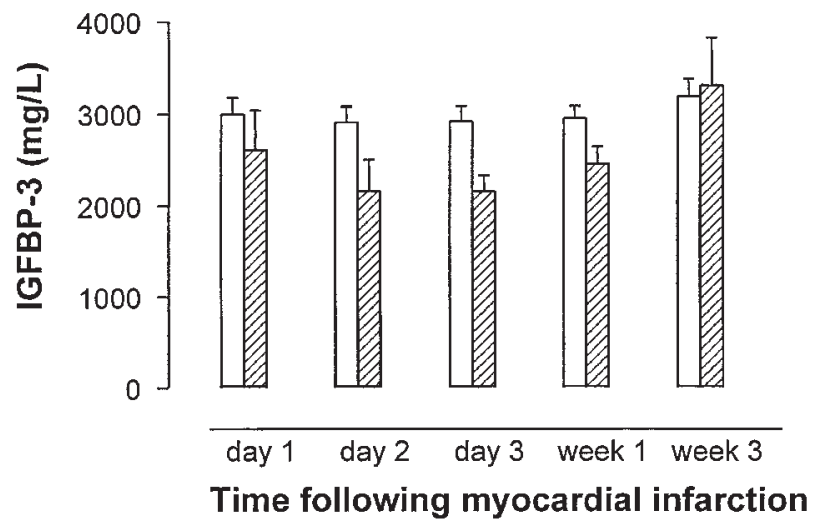

Figure 2 Circulating total IGF-I (A) and IGFBP-3 (B) levels in healthy survivors and patients with poor clinical outcomes after an acute myocardial infarction. Data are means \pm S.E.M. Mean total IGF-I levels were significantly lower in patients who died $(n=2)$ or developed severe congestive HF $(n=4)$ during 3 months of post-acute myocardial infarction follow-up ( ${ }^{\star} P<0.001$ ). In those patients with poor outcomes, a borderline reduction of IGFBP-3 was observed on day $2(P=0.086)$. (Adapted from (83) with permission from The Endocrine Society.) 
cause vascular damage and vascular dysfunction (75). Vascular dysfunction is known to be associated with all major risk factors for atherosclerosis, encompassing hypertension and diabetes mellitus. Because NO is essential for the integrity of the vessel wall, decreased NO production by vascular endothelium, due to low IGF-I levels, might be another pathogenic mechanism responsible for the observed association between low circulating IGF-I levels and atherosclerosis in diabetics and non-diabetics (72). IGF-I can promote vasodilation through the activation of potassium channels, with a consequent reduction in the intracellular calcium concentrations (76-79). In addition, IGF-I can stimulate migration and tube formation by vascular endothelial cells (80), has been shown to promote aortic angiogenesis (81), and inhibits adherence of human peripheral blood monocytes to endothelial cells (82). All these data together suggest a role for IGF-I deficiency per se in increasing the atherosclerotic risk in diabetics and non-diabetics.

\section{IGF-I, diabetes and the heart}

Low circulating IGF-I levels have been previously associated with angiographically documented coronary artery disease (CAD) in non-diabetics (62) (Fig. 1). Immediately after acute myocardial infarction, lowered circulating IGF-I levels were especially measured in non-diabetic patients with poor outcomes (83) (Fig. 2). Recently Friberg et al. (84) reported that non-diabetic patients who died after an acute myocardial infarction from CVD during 2 years of follow-up, had at admission significantly lower IGF-I levels than survivors. In two other studies, non-diabetic patients with myocardial infarction had significantly lower IGF-I levels at admission than age- and sex-matched healthy controls $(85$, $86)$. In one of these latter studies older patients with a cardiac condition were less able to maintain their blood IGF-I levels during the recovery period than younger patients (85) (Fig. 3). The authors suggested that this observation may explain why older patients take longer to recover and to heal after a myocardial infarction than younger patients. These human studies all suggest that lowered circulating IGF-I accounts for a poor outcome of CVD.

Obviously, circulating IGF-I levels can decrease by two mechanisms or their combination: (i) the production of IGF-I is decreased and the efflux from the circulation is unaltered, or (ii) the production is unaltered and the efflux from the circulation is increased, e.g. increased delivery of IGF-I at an injury of the vascular endothelium by an increased proteolysis of circulating IGFBP-3 by specific IGFBP-3 proteases (87). Probably both factors play a role in the reduction of circulating IGF-I.

However, the most important issue in all these human studies is to what extent low circulating IGF-I

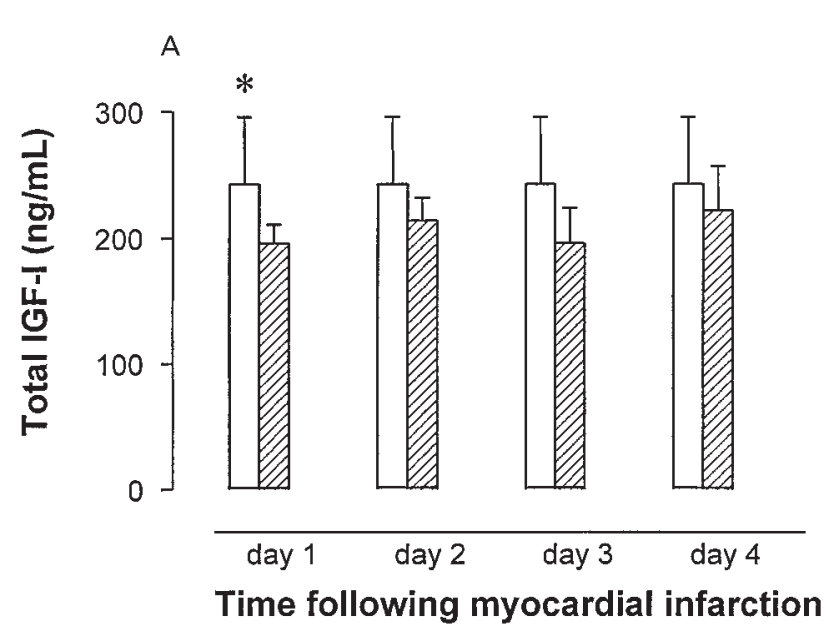

$\square$ Controls <50 yrs $(n=20)$
$\square$ Patients $<50$ yrs $(n=9)$

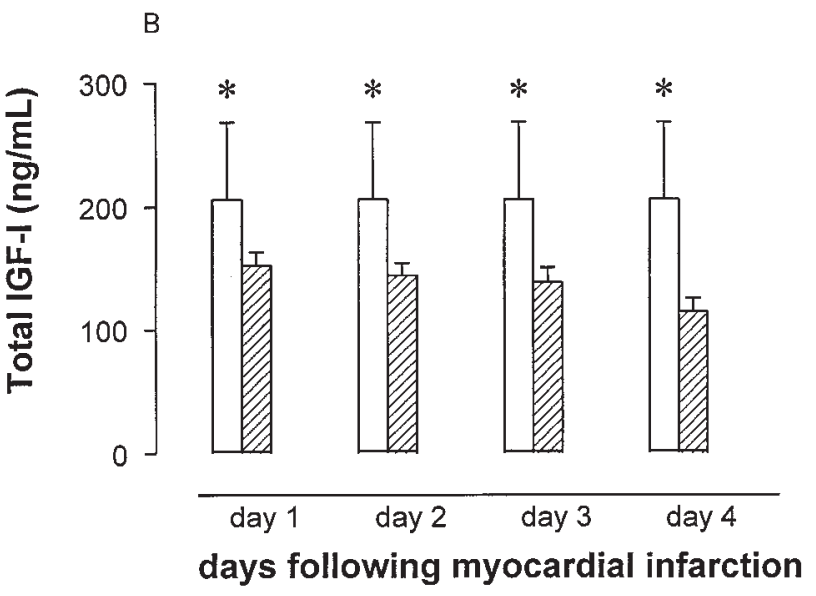

$\square$ Controls $>50$ yrs $(n=50)$
$\square$ Patients $>50$ yrs $(n=17)$

Figure 3 Circulating total IGF-I levels following myocardial infarction compared with age- and sex-adjusted normal adults. Twentyone males and five females ranging in age from 19 to 71 years were divided into two age groups: the first ranging from 19 to 48 years (nine males) (A) and the second ranging from 50 to 71 years (five post-menopausal females and 12 males) (B). Total IGF-I levels in the older age group (B) showed a significant decline from day 1 to day $4(P=0.001)$. Values of the younger age group $(A)$ remained stable from day 1 to day 4 compared with the older group (B). Total IGF-I levels were significantly lower on the first day compared with the age- and sex-adjusted total IGF-I levels of normal adults (controls) aged $<50$ years $(197 \pm 44 \mathrm{vs}$ $243 \pm 53 \mathrm{ng} / \mathrm{ml}, P=0.03$ ) (A) and those aged $>50$ years (151 \pm 43 vs $206 \pm 62 \mathrm{ng} / \mathrm{ml}, P=0.002$ ) (B). In contrast to the younger group, values of total IGF-I in the older group ( $>50$ years) remained significantly lower than those of controls on day 2 to day 4. ${ }^{*} P<0.005$. (Adapted from (85) with permission from Harcourt Publishers Ltd.) 
levels are a cause or a consequence of the poor cardiovascular outcome. In our opinion the decrease in circulating IGF-I levels is probably the cause and not the consequence of the poor outcome of CVD. In the section that follows we will give several arguments to support this statement.

In a rabbit model, acute administration of IGF-I just before and during early cardial ischaemia improves glucose uptake and tolerance to ischaemia in hypertrophied hearts (88). IGF-I has been shown to have beneficial acute and long-term cardiovascular effects in several other experimental studies. Potentially beneficial effects of IGF-I observed in these experimental studies are reduction in afterload through vasodilation, positive inotropy, prevention of apoptosis, increased calcium sensitivity of cardiac myofilaments, improved recovery of cardiac function after myocardial infarction and during reperfusion after global ischaemia (88-92).

In a previous study, as already discussed above, we were able to confirm an increased risk for myocardial infarction in diabetic and non-diabetic subjects with genetically determined low IGF-I expression (59). A genetic approach overcomes the problem that crosssectional studies cannot distinguish whether IGF-I levels are a cause or a consequence of disease. The increased risk for myocardial infarction in diabetics with low IGF-I expression may thus for a large part be explained by the interaction of low IGF-I availability and coronary atherosclerosis. The study of Conti et al. (86) supports this possibility. In this study low IGF-I levels preceded the increase of creatine phosphokinase in the very early phase of an acute myocardial infarction, which suggests also that some antecedent cause and not the acute myocardial infarction was the reason for the lowered IGF-I levels (86). In the same study, patients with acute myocardial infarction showed a trend toward higher insulin levels compared with controls, which achieved statistical significance at 1 year follow-up (86). The authors suggested that these insulin levels were consistent with an insulinresistant state, in both the acute and chronic phases of myocardial infarction.

\section{Experimental evidence for IGF-I effects on the heart}

\section{Effects on CHD}

The importance of IGF-I as an anti-apoptotic factor is also supported by the observation in different animal models of myocardial ischaemia that IGF-I administration decreased myocardial apoptosis and thereby the size of myocardial infarction $(89,93)$. When the coronary artery was ligated to create an experimental myocardial infarction in mice, transgenic mice overexpressing IGF-I in the myocardium showed decreased cell death and less ventricular dilation and wall stress (94). GH-deficient dwarf rats, with reduced circulating IGF-I levels but normal myocardial IGF-I mRNA levels, developed in an experimental model of myocardial infarction more pathological left ventricular remodelling and functional loss than did controls (95). In another experimental model of myocardial infarction a marked reduction in capillarization and a blunted cardiac remodelling response following myocardial infarction were observed in IGF-I-deficient mice, as compared with controls (96).

\section{Diabetic cardiomyopathy}

In most forms of cardiomyopathy there is an initial upregulation of myocardial IGF-I and IGF-I receptor expression, which may be a transient, compensatory remodelling response (97). In contrast, diabetic cardiomyopathy is a unique myopathic state and differs from other cardiomyopathies in that a decrease in both myocardial IGF-I content and IGF-I receptors has been observed (98). However, in IGF-I transgenic mice with streptozotocin-induced diabetes, IGF-I overexpression decreased the development of diabetic cardiomyopathy by attenuating p53 function and angiotensin II production (99). IGF-I improves myocardial function in various models of experimental cardiomyopathy and suppresses myocardial apoptosis (100-102). IGF-I administration in animals with experimental cardiac failure promoted a physiological form of myocardial hypertrophy (i.e. there was no increase in extracellular matrix or fibrosis) (101). The myocardial hypertrophy was accompanied by an improved cardiac function (decreased left ventricular end-diastolic volume and increased stroke volume), suggesting a beneficial effect of IGF-I. In another experimental animal model of HF, IGF-I treatment decreased mean arterial pressure, left ventricular end-diastolic pressure and systemic vascular resistance, and increased left cardiac index and stroke volume index (103).

Recently it was shown that basal IGF-I levels are reduced in dilated cardiomyopathy patients with severe left ventricular dysfunction (104) and that serum IGF-I levels are negatively correlated with the severity of the cardiomyopathy (105). IGF-I improves cardiac contractility, cardiac output, stroke volume and ejection fraction by the human heart in the short and long term (91). Adult humans with GH deficiency and low IGF-I levels display slight cardiac dysfunction, which can be reversed by GH replacement therapy (106). IGF-I exerts calcium-dependent positive inotropic effects in the failing human myocardium (107). All these studies together suggest that IGF-I deficiency may contribute to an adverse outcome of CVD. 


\section{Is decreased IGF-I a missing link which raises both glucose levels and cardiovascular risk in ageing patients with type 2 diabetes?}

Both the prevalence of type 2 diabetes mellitus and CVD are increasing and associated with a very high mortality rate, reduced quality of life and high costs of treatment, despite intensive insulin treatment. New strategies are urgently needed which slow or prevent the development of type 2 diabetes and CVD better than is currently achieved with the available treatment options. Several studies, as discussed above, suggest that the premature and progressive decline in serum IGF-I bioactivity during ageing in patients with type 2 diabetes may result in insufficient protective and regeneration effects of IGF-I on the cardiovascular system. In comparison with other growth factors, these 'survival' effects of IGF-I on the myocardium seem rather unique (108). In addition, IGF-I enhances insulin sensitivity and improves glycaemic control in type 2 diabetic subjects significantly (109). In addition, IGF-I treatment lowers both total and low-density lipoprotein cholesterol and triglyceride levels in type 2 diabetics (110). Lipoprotein(a) (Lp(a)), an important risk factor for CAD, also improved after IGF-I treatment (89). The risk of coronary thrombosis (as measured by plasminogen activator inhibitor-1 and fibrinogen levels) also improved after IGF-I treatment (111). Moreover, IGF-I treatment decreases obesity and improves body composition of type 2 diabetics $(109,112)$. Taking all the available information together, it becomes increasingly clear that IGF-I is not only an important metabolic regulatory hormone but also produces potent effects on the cardiovascular system (see Table 2 for a summary of potential mechanisms). Therefore, we hypothesize that in patients with type 2 diabetes the accelerated decline in serum IGF-I bioactivity during ageing is an important pathophysiological phenomenon, which not only results in raised glucose and lipid levels but also contributes to the progression and the poor outcome of CVD. However, the 'IGF-I deficiency hypothesis' rests still to a great extent on

Table 2 Summary of the potential mechanisms by which IGF-I prevents the progression towards CVD (see also text).

(i) Optimization of the metabolic control

(ii) Regulation of endothelium- and non-endothelium-dependent vascular reactivity

(iii) Maintenance of normal NO bioavailability and consequent activation of anti-atherogenic mechanisms

(iv) Stimulation of angiogenesis

(v) Preservation of left ventricular geometry, stress and systolic and diastolic performance

(vi) Activation of anti-apoptic pathways

(vii) Attenuation of vascular risk factors (visceral adiposity, Lp(a), lipids, etc.) animal studies, which have been extensively referred to in this manuscript, as well as on circumstantial evidence. The decreased serum IGF-I level observed in subjects with type 2 diabetes mellitus with poor glycaemic control raises the possibility that exogenous recombinant IGF-I acting as a form of 'replacement' therapy might improve glucose tolerance and might inhibit the development of CVD (43). Previous studies have demonstrated that in type 2 diabetes circulating IGF-I levels improve after better glycaemic control (43, 113-115). IGF-I therapy as an adjunct to insulin improved glycaemic control in type 2 diabetes and reduced insulin resistance, a major component of the pathophysiology of type 2 diabetes (31). To date, studies of recombinant IGF-I administration to patients with type 2 diabetes have used free IGF-I doses which were associated with significant side-effects (arthralgias, myalgias, dyspnoea, nerve entrapment, headache and bilateral jaw tenderness) (31). These side-effects were probably caused by the use of free IGF-I in excessive doses. IGF-I administration inhibits GH secretion and may therefore actually further decrease IGFBP-3 and acid-labile subunit levels, which will result in a faster clearance of IGF-I from the circulation and thus more side-effects (116). Most pharmaceutical companies have decided not to develop IGF-I treatment further because of these side-effects (117). Recently, shortterm clinical trials using a complex of IGF-I/IGFBP-3 as an adjuvant to insulin therapy in patients with type 2 diabetes caused a rapid fall in plasma glucose concentrations and an improvement in insulin resistance without any side-effects (118). There is as yet no proof that (long-term replacement) therapy with IGF-I as an adjunct to insulin will reduce, delay or even prevent the risk of CVD in patients with type 2 diabetes. Further studies examining the efficacy and the long-term safety of this IGF-I/IGFBP-3 combination should be undertaken in patients with type 2 diabetes, to investigate if this complex can modify the incidence and prevalence of CVD in these patients.

\section{References}

1 Kannel WB \& McGee DL. Diabetes and cardiovascular disease. The Framingham study. Journal of the American Medical Association $19792412035-2038$.

2 Laakso M. Cardiovascular disease in type 2 diabetes: challenge for treatment and prevention. Journal of Internal Medicine 2001 $249225-235$.

3 Abbott RD, Donahue RP, MacMahon SW, Reed DM \& Yano K. Diabetes and the risk of stroke. The Honolulu Heart Program. Journal of the American Medical Association 1987257 949-952.

4 Morris AD, McAlpine R, Steinke D, Boyle DI, Ebrahim AR, Vasudev $\mathrm{N}$ et al. Diabetes and lower-limb amputations in the community. A retrospective cohort study. DARTS/MEMO Collaboration. Diabetes Audit and Research in Tayside Scotland/Medicines Monitoring Unit. Diabetes Care 199821 738-743.

5 Cohen DL, Neil HA, Thorogood M \& Mann JI. A population-based study of the incidence of complications associated with type 2 diabetes in the elderly. Diabetic Medicine $19918928-933$. 
6 Vokonas PS \& Kannel WB. Diabetes mellitus and coronary heart disease in the elderly. Clinical Geriatric Medicine 199612 69-78.

7 Davis TM, Stratton IM, Fox CJ, Holman RR \& Turner RC. UK Prospective Diabetes Study 22. Effect of age at diagnosis on diabetic tissue damage during the first 6 years of NIDDM. Diabetes Care $1997201435-1441$

8 Miettinen H, Lehto S, Salomaa V, Mahonen M, Niemela M, Haffner SM et al. Impact of diabetes on mortality after the first myocardial infarction. The FINMONICA Myocardial Infarction Register Study Group. Diabetes Care 199821 69-75.

9 Summary of the second report of the National Cholesterol Education Program (NCEP) Expert Panel on Detection, Evaluation, and Treatment of High Blood Cholesterol in Adults (Adult Treatment Panel II). Journal of the American Medical Association 1993 269 3015-3023.

10 Hayden JM \& Reaven PD. Cardiovascular disease in diabetes mellitus type 2: a potential role for novel cardiovascular risk factors. Current Opinion in Lipidology 200011 519-528.

$11 \mathrm{Gu} \mathrm{K}$, Cowie CC \& Harris MI. Diabetes and decline in heart disease. Journal of the American Medical Association $1999 \mathbf{2 8 1}$ 1291-1297.

12 Kannel WB, Hjortland M \& Castelli WP. Role of diabetes in congestive heart failure: the Framingham study. American Journal of Cardiology $19743429-34$.

13 Zarich SW \& Nesto RW. Diabetic cardiomyopathy. American Heart Journal 1989118 1000-1012.

14 Sowers JR, Epstein M \& Frolich ED. Diabetes, hypertension, and cardiovascular disease. Hypertension 200137 1053-1059.

15 Nichols GA, Hillier TA, Erbey JR \& Brown JB. Congestive heart failure in type 2 diabetes: prevalence, incidence, and risk factors. Diabetes Care 200124 1614-1619.

16 Iribarren C, Karter AJ, Go AS, Ferrara A, Liu JY, Sidney S et al. Glycemic control and heart failure among adult patients with diabetes. Circulation 2001103 2668-2673.

17 Mogensen CE. Combined high blood pressure and glucose in type 2 diabetes: double jeopardy. British trial shows clear effects of treatment, especially blood pressure reduction. British Medical Journal 1998317 693-694.

18 Stratton IM, Adler AI, Neil HA, Matthews DR, Manley SE, Cull CA et al. Association of glycaemia with macrovascular and microvascular complications of type 2 diabetes (UKPDS 35): prospective observational study. British Medical Journal $2000 \mathbf{3 2 1}$ 405-412.

19 Suzuki LA, Poot M, Gerrity RG \& Bornfeldt KE. Diabetes accelerates smooth muscle accumulation in lesions of atherosclerosis. Diabetes $200150851-860$.

20 Nolan JJ \& Murphy E. Does impaired glucose tolerance really exist, and if so what should be done about it? In Difficult Diabetes, ch 2, pp 22-35. Eds G Gill, J Pickup \& G Williams. Oxford: Blackwell Science, 2001.

21 Fuller JH, Shipley MJ, Rose G, Jarrett RJ \& Keen H. Coronaryheart-disease risk and impaired glucose tolerance. The Whitehall study. Lancet 19801 1373-1376.

22 Donahue RP, Abbott RD, Reed DM \& Yano K. Postchallenge glucose concentration and coronary heart disease in men of Japanese ancestry. Honolulu Heart Program. Diabetes 198736 689-692.

23 Scheidt-Nave C, Barrett-Connor E, Wingard DL, Cohn BA \& Edelstein SL. Sex differences in fasting glycemia as a risk factor for ischemic heart disease death. American Journal of Epidemiology $1991133565-576$

24 Gerstein HC. Glucose: a continuous risk factor for cardiovascular disease. Diabetic Medicine 199724 (Suppl 3) S25-S31.

25 Reaven GM. Pathophysiology of insulin resistance in human disease. Physiological Reviews 199575 473-486.

26 Quattrin T, Thrailkill K, Baker L, Kuntze J, Compton P \& Martha $\mathrm{P}$. Improvement of $\mathrm{HbA}(1 \mathrm{c})$ without increased hypoglycemia in adolescents and young adults with type 1 diabetes mellitus treated with recombinant human insulin-like growth factor-I and insulin. Journal of Pediatric Endocrinology and Metabolism $2001 \mathbf{1 4}$ $267-277$.
27 Boulware SD, Tamborlane WV, Matthews LS \& Sherwin RS. Diverse effects of insulin-like growth factor I on glucose, lipid, and amino acid metabolism. American Journal of Physiology 1992262 E130-E133.

28 Phillips LS, Harp JB, Goldstein S, Klein J \& Pao CI. Regulation and action of insulin-like growth factors at the cellular level. Proceedings of the Nutrition Society $1990 \mathbf{4 9} 451-458$.

29 Rennert NJ, Caprio S \& Sherwin RS. Insulin-like growth factor I inhibits glucose-stimulated insulin secretion but does not impair glucose metabolism in normal humans. Journal of Clinical Endocrinology and Metabolism 199376 804-806.

30 Schoenle EJ, Zenobi PD, Torresani T, Werder EA, Zachmann M \& Froesch ER. Recombinant human insulin-like growth factor I (rhIGF I) reduces hyperglycaemia in patients with extreme insulin resistance. Diabetologia 199134 675-679.

31 Moses AC, Young SC, Morrow LA, O'Brien M \& Clemmons DR. Recombinant human insulin-like growth factor I increases insulin sensitivity and improves glycemic control in type II diabetes. Diabetes $1996 \mathbf{4 5} 91-100$

32 Froesch ER, Hussain M, Schmid \& Zapf J. Insulin-like growth factors. In Ellenberg and Rifkin's Diabetes Mellitus, pp 95-114. Eds D Porte Jr \& RS Sherwin. Stamford, Connecticut, USA: Appleton \& Lange, 1997.

33 Collett-Solberg PF \& Cohen P. The role of the insulin-like growth factor binding proteins and the IGFBP proteases in modulating IGF action. Endocrinology and Metabolism Clinics of North America $199625591-614$.

34 Binoux M. The IGF system in metabolism regulation. Diabetes and Metabolism 199521 330-337.

35 Janssen JAMJL \& Lamberts SWJ. Is the measurement of free IGF-I more indicative than that of total IGF-I in the evaluation of the biological activity of the GH/IGF-I axis? Journal of Endocrinological Investigation 199922 313-315.

36 Bang P, Brismar K \& Rosenfeld R. Increased proteolysis of insulin-like growth factor binding protein-3 (IGFBP-3) in noninsulin-dependent diabetes mellitus serum, with elevation of 29-kilodalton (kDa) glycosylated IGFBP-3 fragment contained in the approximately 130 - to $150-\mathrm{kDa}$ ternary complex. Journal of Clinical Endocrinology and Metabolism 199478 1119-1127.

37 Meneilly GS \& Tessier D. Diabetes in the elderly. In Endocrinology of Aging, ch 12, pp 181-203. Eds JE Morley \& L Van den Berg. Totowa, New Jersey, USA: Humana Press Inc., 2000.

38 Lemne C \& Brismar $\mathrm{K}$. Insulin-like growth factor binding protein-1 as a marker of the metabolic syndrome - a study in borderline hypertension. Blood Pressure 19987 89-95.

39 Froesch ER. Insulin-like growth factor: endocrine and autocrine/ paracrine implications and relations to diabetes mellitus. In Contributions of Physiology to the Understanding of Diabetes. Ten Essays in Memory of Albert E Renold, pp 127-147. Eds GR Zahnd \& CB Wollheim. Berlin: Springer-Verlag, 1997.

40 Gabbay RA \& Moses AC. IGF in the treatment of diabetes. In Contemporary Endocrinology: the IGF System, ch 30, pp 721-737. Eds R Rosenfeld \& C Roberts Jr. Totowa, New Jersey, USA: Humana Press Inc., 1999.

41 Garay-Sevilla ME, Nava LE, Malacara JM, Wrobel K, Wrobel K \& Perez U. Advanced glycosylation end products (AGEs), insulinlike growth factor-I (IGF-I) and IGF-binding protein-3 (IGFBP3 ) in patients with type 2 diabetes mellitus. Diabetes/Metabolism Research and Reviews 200016 106-113.

42 Paolisso G, Tagliamonte MR, Rizzo MR, Carella C, Gambardella A, Barbieri M et al. Low plasma insulin-like growth factor-I concentrations predict worsening of insulin-mediated glucose uptake in older people. Journal of the American Geriatric Society $1999471312-1318$.

43 Moses AC. Recombinant insulin-like growth factor-I as therapy in states of altered carbohydrate homeostasis. Current opinion in Endocrinology and Metabolism 19974 16-25.

44 Tan K \& Baxter RC. Serum insulin-like growth factor I levels in adult diabetic patients: the effect of age. Journal of Clinical Endocrinology and Metabolism $1986 \mathbf{6 3} 651-655$. 
45 Bang P, Brismar K, Rosenfeld RG \& Hall K. Fasting affects serum insulin-like growth factors (IGFs) and IGF-binding proteins differently in patients with noninsulin-dependent diabetes mellitus versus healthy nonobese and obese subjects. Journal of Clinical Endocrinology and Metabolism 1994 78 960-967.

46 Bang P, Nygren J, Carlsson-Skwirut C, Thorell A \& Ljungqvist O. Postoperative induction of insulin-like growth factor binding protein-3 proteolytic activity: relation to insulin and insulin sensitivity. Journal of Clinical Endocrinology and Metabolism $1998832509-2515$.

47 Zachrisson I, Brismar K, Carlsson-Skwirut C, Dahlquist G, Wallensteen M \& Bang P. Increased $24 \mathrm{~h}$ mean insulin-like growth factor binding protein-3 proteolytic activity in pubertal type 1 diabetic boys. Growth Hormone and IGF Research 2000 $10324-331$.

48 Lassarre C, Duron F \& Binoux M. Use of the ligand immunofunctional assay for human insulin-like growth factor (IGF) binding protein-3 (IGFBP-3) to analyze IGFBP-3 proteolysis and IGF-I bioavailability in healthy adults. GH-deficient and acromegalic patients, and diabetics. Journal of Clinical Endocrinology and Metabolism $2001861942-1952$.

49 Buchanan TA. Pancreatic B-cell defects in gestational diabetes: implications for the pathogenesis and prevention of type 2 diabetes. Journal of Clinical Endocrinology and Metabolism 2001 86 989-993.

50 Heald AH, Cruickshank JK, Riste LK, Cade JE, Anderson S, Greenhalgh A et al. Close relation of fasting insulin-like growth factor binding protein-1 (IGFBP-1) with glucose tolerance and cardiovascular risk in two populations. Diabetologia $200144333-339$.

51 Cusi K \& DeFronzo R. Treatment of NIDDM, IDDM and other insulin resistant states with IGF-I. Diabetes Reviews 19953 206-236.

52 Clauson PG, Brismar K, Hall K, Linnarsson R \& Grill V. Insulinlike growth factor-I and insulin-like growth factor binding protein-1 in a representative population of type 2 diabetic patients in Sweden. Scandinavian Journal of Clinical and Laboratory Investigation $1998 \mathbf{5 8} 353-360$.

53 Chen M, Bergman RN, Pacini G \& Porte D Jr. Pathogenesis of age-related glucose intolerance in man: insulin resistance and decreased beta-cell function. Journal of Clinical Endocrinology and Metabolism $1985 \mathbf{6 0} 13-20$.

54 Gumbiner B, Polonsky KS, Beltz WF, Wallace P, Brechtel G \& Fink RI. Effects of aging on insulin secretion. Diabetes 198938 $1549-1556$.

55 Rutanen EM, Karkkainen T, Stenman UH \& Yki-Jarvinen H. Aging is associated with decreased suppression of insulin-like growth factor binding protein-1 by insulin. Journal of Clinical Endocrinology and Metabolism 199377 1152-1155.

56 Taylor AM, Dunger DB, Preece MA, Holly JM, Smith CP, Wass JA et al. The growth hormone independent insulin-like growth factor-I binding protein BP-28 is associated with serum insulinlike growth factor-I inhibitory bioactivity in adolescent insulindependent diabetics. Clinical Endocrinology 199032 229-239.

57 Lewitt MS, Denyer GS, Cooney GJ \& Baxter RC. Insulin-like growth factor-binding protein-1 modulates blood glucose levels. Endocrinology 1991129 2254-2256.

58 Janssen JAMJL \& Lamberts SWJ. Circulating IGF-I and its protective role in the pathogenesis of diabetic angiopathy. Clinical Endocrinology $2000 \mathbf{5 2} 1-9$.

59 Vaessen N, Heutink P, Janssen JA, Witteman JC, Testers L, Hofman A et al. A polymorphism in the gene for IGF-I: functional properties and risk for type 2 diabetes and myocardial infarction. Diabetes $200150637-642$.

60 Rosen T \& Bengtsson BA. Premature mortality due to cardiovascular disease in hypopituitarism. Lancet 1990336 285-288.

61 Markussis V, Beshyah SA, Fisher C, Sharp P, Nicolaides AN \& Johnston DG. Detection of premature atherosclerosis by highresolution ultrasonography in symptom-free hypopituitary adults. Lancet $1992 \mathbf{3 4 0} 1188-1192$.
62 Spallarossa P, Brunelli C, Minuto F, Caruso D, Battistini M, Caponnetto $\mathrm{S}$ et al. Insulin-like growth factor-I and angiographically documented coronary artery disease. American Journal of Cardiology 199677 200-202.

63 Janssen JAMJL, Stolk RP, Pols HAP, Grobbee DE \& Lamberts SWJ. Serum total IGF-I, free IGF-I, and IGFB-1 levels in an elderly population: relation to cardiovascular risk factors and disease. Arteriosclerosis, Thrombosis, and Vascular Biology $1998 \mathbf{1 8}$ 277-282.

64 Tiell ML, Stemerman MB \& Spaet TH. The influence of the pituitary on arterial intimal proliferation in the rat. Circulation Research $1978 \mathbf{4 2} 644-649$.

65 Okura Y, Brink M, Zahid AA, Anwar A \& Delafontaine P. Decreased expression of insulin-like growth factor-I and apoptosis of vascular smooth muscle cells in human atherosclerotic plaque. Journal of Molecular and Cellular Cardiology 200133 1777-1789.

66 Bennett MR, Evan GI \& Schwartz SM. Apoptosis of human vascular smooth muscle cells derived from normal vessels and coronary atherosclerotic plaques. Journal of Clinical Investigation $1995952266-2274$.

$67 \mathrm{Du}$ J \& Delafontaine P. Inhibition of vascular smooth muscle cell growth through antisense transcription of a rat insulin-like growth factor I receptor cDNA. Circulation Research 199576 963-972.

68 Bornfeldt KE, Raines EW, Nakano T, Graves LM, Krebs EG \& Ross R. Insulin-like growth factor-I and platelet-derived growth factor-BB induce directed migration of human arterial smooth muscle cells via signaling pathways that are distinct from those of proliferation. Journal of Clinical Investigation 199493 1266-1274.

69 Bornfeldt K \& Arnqvist HJ. Actions of insulin-like growth factor I and insulin in vascular smooth muscle: receptor interaction and growth-promoting effects. In Growth Hormone and Insulin-like Growth Factor-I, ch 7, pp 159-188. Eds A Flyvbjerg, H Ørskov \& KGGM Alberti. Chicester: John Wiley \& Sons, 1993.

70 Walsh MF, Barazi M, Pete G, Muniyappa R, Dunbar JC \& Sowers JR. Insulin-like growth factor I diminishes in vivo and in vitro vascular contractility: role of vascular nitric oxide. Endocrinology $19961371798-1803$.

71 Muniyappa R, Walsh MF, Rangi JS, Zayas RM, Standley PR, Ram JL et al. Insulin like growth factor I increases vascular smooth muscle nitric oxide production. Life Science 199761 925-931.

72 Haylor J, Singh I \& el Nahas AM. Nitric oxide synthesis inhibitor prevents vasodilation by insulin-like growth factor I. Kidney International $199139333-335$.

73 Copeland KC \& Nair KS. Recombinant human insulin-like growth factor-I increases forearm blood flow. Journal of Clinical Endocrinology and Metabolism 199479 230-232.

74 Schini-Kerth VB. Dual effects of insulin-like growth factor-I on the constitutive and inducible nitric oxide (NO) synthase-dependent formation of NO in vascular cells. Journal of Endocrinological Investigation 199922 (Suppl 5) 82-88.

75 Luscher TF \& Noll G. The pathogenesis of cardiovascular disease: role of the endothelium as a target and mediator. Atherosclerosis 1995118 (Suppl) S81-S90.

76 Capaldo B, Guardasole V, Pardo F, Matarazzo M, Di Rella F, Numis F et al. Abnormal vascular reactivity in growth hormone deficiency. Circulation 2001103 520-524.

77 Izhar U, Hasdai D, Richardson DM, Cohen P \& Lerman A. Insulin and insulin-like growth factor-I cause vasorelaxation in human vessels in vitro. Coronary Artery Disease 200011 69-76.

78 Standley PR, Zhang F, Zayas RM, Muniyappa R, Walsh MF, Cragoe $\mathrm{E}$ et al. IGF-I regulation of $\mathrm{Na}(+)-\mathrm{K}(+)$-ATPase in rat arterial smooth muscle. American Journal of Physiology 1997 273 E113-E121.

79 Hasdai D, Rizza RA, Holmes DR Jr, Richardson DM, Cohen P \& Lerman A. Insulin and insulin-like growth factor-I cause coronary vasorelaxation in vitro. Hypertension 199832 228-234. 
80 Nakao-Hayashi J, Ito H, Kanayasu T, Morita I \& Murota S. Stimulatory effects of insulin and insulin-like growth factor I on migration and tube formation by vascular endothelial cells. Atherosclerosis 199292 141-149.

81 Nicosia RF, Nicosia SV \& Smith M. Vascular endothelial growth factor, platelet-derived growth factor, and insulin-like growth factor-I promote rat aortic angiogenesis in vitro. American Journal of Pathology 1994145 1023-1029.

82 Motani A, Forster L, Tull S, Anggard EE \& Ferns GA. Insulin-like growth factor-I modulates monocyte adhesion to EAhy 926 endothelial cells. International Journal of Experimental Pathology $19967731-35$.

83 Lee WL, Chen JW, Ting CT, Lin SJ \& Wang PH. Changes of the insulin-like growth factor I system during acute myocardial infarction: implications on left ventricular remodeling. Journal of Clinical Endocrinology and Metabolism 199984 1575-1581.

84 Friberg L, Werner S, Eggertsen G \& Ahnve S. Growth hormone and insulin-like growth factor-I in acute myocardial infarction. European Heart Journal 200021 1547-1554.

85 Reeves I, Abribat T, Laramee P, Jasmin G \& Brazeau P. Agerelated serum level of insulin-like growth factor-I, -II and IGFbinding protein-3 following myocardial infarction. Growth Hormone and IGF Research $20001078-84$.

86 Conti E, Andreotti F, Sciahbasi A, Riccardi P, Marra G, Menini E et al. Markedly reduced insulin-like growth factor-I in the acute phase of myocardial infarction. Journal of the American College of Cardiology 200138 26-32.

87 Booth BA, Boes M \& Bar RS. IGFBP-3 proteolysis by plasmin, thrombin, serum: heparin binding, IGF binding, and structure of fragments. American Journal of Physiology 1996271 E465-E470.

88 Friehs I, Stamm C, Cao-Danh H, McGowan FX \& del Nido PJ. Insulin-like growth factor-I improves postischemic recovery in hypertrophied hearts. Annals of Thoracic Surgery 200172 1650-1656.

89 Buerke M, Murohara T, Skurk C, Nuss C, Tomaselli K \& Lefer AM. Cardioprotective effect of insulin-like growth factor I in myocardial ischemia followed by reperfusion. PNAS 199592 8031-8035.

90 Cittadini A, Ishiguro Y, Stromer H, Spindler M, Moses AC, Clark $\mathrm{R}$ et al. Insulin-like growth factor-I but not growth hormone augments mammalian myocardial contractility by sensitizing the myofilament to $\mathrm{Ca}^{2+}$ through a wortmannin-sensitive pathway: studies in rat and ferret isolated muscles. Circulation Research 199883 50-59.

91 Donath MY, Sutsch G, Yan XW, Piva B, Brunner HP, Glatz Y et al. Acute cardiovascular effects of insulin-like growth factor I in patients with chronic heart failure. Journal of Clinical Endocrinology and Metabolism 199883 3177-3183.

92 Otani H, Yamamura T, Nakao Y, Hattori R, Kawaguchi H, Osako $\mathrm{M}$ et al. Insulin-like growth factor-I improves recovery of cardiac performance during reperfusion in isolated rat heart by a wortmannin-sensitive mechanism. Journal of Cardiovascular Pharmacology 200035 275-281.

93 Li B, Setoguchi M, Wang X, Andreoli AM, Leri A, Malhotra A et al. Insulin-like growth factor-I attenuates the detrimental impact of nonocclusive coronary artery constriction on the heart. Circulation Research 199984 1007-1019.

94 Li Q, Li B, Wang X, Leri A, Jana K, Liu Yet al. Overexpression of insulin-like growth factor I in mice protects from myocyte death after infarction, attenuating ventricular dilation, wall stress, and cardiac hypertrophy. Journal of Clinical Investigation 1997100 1991-1999.

95 Cittadini A, Grossman JD, Stromer H, Katz SE, Morgan JP \& Douglas PS. Importance of an intact growth hormone/insulin like growth factor I axis for normal post-infarction healing: studies in dwarf rats. Endocrinology 2001142 332-338.

96 Palmen M, Daemen MJ, Bronsaer R, Dassen WR, Zandbergen HR, Kockx M et al. Cardiac remodeling after myocardial infarction is impaired in IGF-I deficient mice. Cardiovascular Research 2001 50 $516-524$.
97 Wang L, Ma W, Markovich R, Chen JW \& Wang PH. Regulation of cardiomyocyte apoptotic signaling by insulin-like growth factor I. Circulation Research $1998 \mathbf{8 3} 516-522$.

98 Bornfeldt KE, Gidlof RA, Wasteson A, Lake M, Skottner A \& Arnqvist HJ. Binding and biological effects of insulin, insulin analogues and insulin-like growth factors in rat aortic smooth muscle cells. Comparison of maximal growth promoting activities. Diabetologia 199134 307-313.

99 Kajstura J, Fiordaliso F, Andreoli AM, Li B, Chimenti S, Medow MS et al. IGF-I overexpression inhibits the development of diabetic cardiomyopathy and angiotensin II-mediated oxidative stress. Diabetes 200150 1414-1424.

100 Ambler GR, Johnston BM, Maxwell L, Gavin JB \& Gluckman PD. Improvement of doxorubicin induced cardiomyopathy in rats treated with insulin-like growth factor I. Cardiovascular Research $1993271368-1373$.

101 Duerr RL, Huang S, Miraliakbar HR, Clark R, Chien KR \& Ross J. Insulin-like growth factor-I enhances ventricular hypertrophy and function during the onset of experimental cardiac failure. Journal of Clinical Investigation 199595 619-627.

102 Cittadini A, Stromer H, Katz SE, Clark R, Moses AC, Morgan JP et al. Differential cardiac effects of growth hormone and insulinlike growth factor-I in the rat: a combined in vivo and in vitro evaluation. Circulation 199693 800-809.

103 Jin H, Yang R, Gillett N, Clark RG, Ko A \& Paoni NF. Beneficial effects of growth hormone and insulin-like growth factor-I in experimental heart failure in rats treated with chronic ACE inhibition. Journal of Cardiovascular Pharmacology 199526 $420-425$.

104 Broglio F, Fubini A, Morello M, Arvat E, Aimaretti G, Gianotti L et al. Activity of GH/IGF-I axis in patients with dilated cardiomyopathy. Clinical Endocrinology 199950 417-430.

105 Osterziel KJ, Ranke MB, Strohm O \& Dietz R. The somatotrophic system in patients with dilated cardiomyopathy: relation of insulin-like growth factor-I and its alterations during growth hormone therapy to cardiac function. Clinical Endocrinology 200053 61-68.

106 Cittadini A, Cuocolo A, Merola B, Fazio S, Sabatini D, Nicolai E et al. Impaired cardiac performance in GH-deficient adults and its improvement after GH replacement. American Journal of Physiology 1994267 E219-E225.

107 Von Lewinski D, Voss K, Bisping E, Pieske B \& Busch T. IGF-I exerts receptor-mediated and $\mathrm{Ca}^{2+}$-dependent positive inotropic effects in failing human myocardium. European Heart Journal 200122 (Suppl S) 301-301.

108 Wang PH. Roads to survival: insulin-like growth factor-I signaling pathways in cardiac muscle. Circulation Research 200188 $552-554$

109 RhIGF-I in NIDDM Study Group. Evidence from a dose-ranging study that recombinant insulin-like growth factor-I (RhIGF-I) effectively and safely improves glycemic control in non-insulin diabetes mellitus. Diabetes 199645 (Suppl 2) 27A.

110 Zenobi PD, Holzmann P, Glatz Y, Riesen WF \& Froesch ER. Improvement of lipid profile in type 2 (non-insulin-dependent) diabetes mellitus by insulin-like growth factor I. Diabetologia $199336465-469$.

111 Padayatty SJ, Orme S, Zenobi PD, Stickland MH, Belchetz PE \& Grant PJ. The effects of insulin-like growth factor-I on plasminogen activator inhibitor-1 synthesis and secretion: results from in vitro and in vivo studies. Thrombosis and Haemostasis $1993 \mathbf{7 0}$ $1009-1013$

112 Moses A, Philips L, Martha P, Compton P \& Zysow B, for the RINDS and RICS Groups. RhIGF-I improves coronary risk factors in type II diabetes. Diabetalogia 199740 (Suppl 1) 1484 (Abstract).

113 Rosato MT, Schneider SH \& Shapses SA. Bone turnover and insulin-like growth factor I levels increase after improved glycemic control in noninsulin-dependent diabetes mellitus. Calcified Tissue International 199863 107-111.

114 Poulos JE, Leggett-Frazier N, Khazanie P, Long S, Sportsman R, MacDonald $\mathrm{K}$ et al. Circulating insulin-like growth factor I 
concentrations in clinically severe obese patients with and without NIDDM in response to weight loss. Hormone and Metabolic Research 199426 478-480.

115 Rieu M \& Binoux M. Serum levels of insulin-like growth factor (IGF) and IGF binding protein in insulin-dependent diabetics during an episode of severe metabolic decompensation and the recovery phase. Journal of Clinical Endocrinology Metabolism $198560781-785$.

116 Leroith D, Bondy C, Yakar S, Liu J-L \& Butler A. The somatomedin hypothesis: 2001. Endocrine Reviews 200122 53-74.
117 Mitchell P. Cancelled IGF-I trials bode ill for diabetic patients. Lancet $19973 \mathbf{5 0} 1606$.

118 Moses AC. Treatment of diabetes mellitus with IGF-I/IGFBP-3. The 83rd Annual Meeting of the Endocrine Society, Denver, CO, 20-23 June, 2001.

Received 12 November 2001

Accepted 7 January 2002 